\title{
Analisis Kepuasan Kerja dan Produktivitas Penyuluh Pertanian di Kecamatan Lumbis, Kabupaten Nunukan
}

\section{Analysis of Job Satisfaction and Productivity of Agricultural Extension Workers in Lumbis District, Nunukan Regency}

\author{
Nia Kurniasih Suryana \\ Program Studi Agribisnis, Fakultas Pertanian, Universitas Borneo Tarakan \\ zlynia@gmail.com
}

INFO ARTIKEL ABSTRACT / ABSTRAK

\begin{abstract}
Sejarah Artikel
Dikirim:

11 Juli 2021

Keberhasilan program penyuluhan tidak lepas dari tanggung jawab bersama antara penyuluh dan petani. Peningkatan produktivitas pertanian harus diimbangi oleh meningkatnya produktivitas kerja penyuluh pertanian. Produktivitas kerja yang tinggi harus diawali oleh penyuluh dengan memiliki motivasi yang kuat dalam menjalankan tugas-tugasnya, memiliki kepuasan terhadap

Diterima: pekerjaannya, sehingga penyuluh akan terus berusaha meningkatkan produktivitas kerjanya. Penelitian ini bertujuan untuk mengetahui factor-faktor yang mempengaruhi kepuasan kerja penyuluh di Kecamatan Lumbis dan mengetahui hubungan kepuasan kerja penyuluh dengan produktivitas kerja penyuluh di Kecamatan Lumbis. Analisis data yang digunakan adalah analisis

Terbit: regresi linier berganda dan analisis korelasi. Hasil penelitian menunjukan bahwa variabel psikologi (X1), sosial (X2), dan finansial (X4), mempengaruhi kepuasan kerja penyuluh di Kecamatan Lumbis dengan nilai signifikansi 0,000 pada taraf 5\% atau 0,05 dan Hubungan antara kepuasan kerja penyuluh dengan produktivitas kerja penyuluh kuat, dengan koefisien korelasi sebesar 0.643 artinya tingkat kekuatan hubungan (korelasi) antar variabel kepuasan kerja penyuluh dengan produktivitas kerja penyuluh adalah sebesar 0.643.
\end{abstract}

The success of the extension program cannot be separated from the joint responsibility between the extension workers and farmers. Increased agricultural productivity must be balanced by increased productivity by agricultural extension work. High work productivity must be preceded by extension workers with strong motivation in carrying out their duties, having satisfaction with his work, so that extension workers will continue to strive to improve work productivity. This study aims to determine the factors that influence the job satisfaction of extension workers in Lumbis District and determine the relationship of job satisfaction with extension workers productivity in Lumbis District. Analysis of the data used is multiple linear regression analysis and correlation analysis. The results showed that the variables of psychology (X1), social (X2), and financial (X4), affect the job satisfaction of extension workers in the District of Lumbis with a significance value of 0,000 at the level of $5 \%$ or 0.05 and The relationship between job satisfaction and productivity of worker extension is strong, with a correlation coefficient of 0.643 it means that the level of correlation strength between the variables of job satisfaction with job productivity is 0.643 .

This is an open access article under the CC-BY license.

Kata Kunci: Kepuasan kerja, produktivitas kerja, penyuluh pertanian

Keywords: Job satisfaction, work productivity, agricultural extension workers

\section{Pendahuluan}

Upaya peningkatan sumberdaya manusia (SDM) pertanian, terutama SDM petani, dapat dilakukan melalui kegiatan penyuluhan pertanian, karena penyuluhan merupakan salah satu kegiatan yang strategis dalam upaya pencapaian tujuan pembangunan pertanian. Penyuluh pertanian sebagai bagian integral pembangunan di bidang pertanian merupakan salah satu upaya kemandirian petani dan pelaku usaha pertanian lainnya untuk meningkatkan produktivitas, pendapatan dan kesejahterannya.

Peran penyuluh berpengaruh terhadap keberdayaan masyarakat, karena dapat mewujudkan kemandirian masyarakat melalui peningkatan pengetahuan, keterampilan dan sikap (Suryana, 2018). Penyuluh Pertanian Lapangan (PPL) sebagai komunikator pembangunan diharapkan dapat bermain multiperan, sebagai guru, 
pembimbing, penasehat, penyampai informasi dan mitrapetani. Karena itu, peningkatan kinerja penyuluh sangat penting di dalam mempertahankan kelangsungan program penyuluhan di tingkat lapangan.

Keberhasilan proses penyuluh salah satunya ditentukan oleh produktivitas dan kepuasan kerja penyuluh, Kepuasan kerja merupakan seperangkat seseorang tentang menyenangkan atau tidaknya pekerjaannya. Kepuasan kerja pada dasarnya merupakan hal yang bersifat individual, setiap individual memiliki tingkat kepuasan kerja yang berbeda-beda sesuai dengan keinginan dan sistem nilai yang dianutnya (Handoko, 2001). Kepuasan kerja mengacu pada sikap umum seseoaran terhadap pekerjaannya, dengan demikian kepuasan kerja bersifat individual (Puspadi, 2002). Kepuasan kerja merupakan cara pandang seseorang baik bersifat positif maupun bersifat negatif tentang pekerjaannya. Ketika seseorang merasakan kepuasan dalam bekerja tentunya ia akan berupaya semaksimal mungkin dengan segenap kemampuan yang dimilikinya untuk menyelesaikan tugas pekerjaannya. Dengan demikian produktivitas dan hasil kerja akan meningkat secara optimal.

Kecamatan Lumbis terdiri atas 28 desa sebagian besar merupakan penduduk asli yaitu Suku Dayak Agabag, memiliki jumlah penyuluh sebanyak 30 orang. Pemerintahan Kecamatan Lumbis berpusat di desa Mansalong. Penyuluh memiliki kewenangan dan tanggungjawab yang tinggi dalam pengambilan keputusan mengenai apa dan bagaimana pelaksanaan penyuluhan di wilayah binaannya (Suryana, 2021). Banyak masalah yang dialami oleh penyuluh di Kecamatan Lumbis dalam melaksanakan kegiatan penyuluhan diantaranya kurangnya dukungan dalam penyelenggaraan penyuluhan dilapangan, sementara itu penyuluhan memerlukan kerterpaduan, keterkaiatan dan koordinasi dengan instansi yang yang terkait dengan pelaksanaannya. Inti kegiatan penyuluh adalah membentuk petani mengatasi fenomena usaha taninya agar mereka dapat mencapai tujuan usaha taninya. Jaringan kerja antar penyuluh sebagai penyampai inforamasi masih sangat lemah sehingga diperlukan kerja sama dalam hal penyediaan informasi dan teknologi guna mempercepat keberhasilan pembangunan pertanian di Kecamatan Lumbis. Selain itu dukungan APBD yang belum optimal dalam penyelenggaraan penyuluhan menghambat terlaksananya kegiatan penyuluh di lapangan. Dengan demikian perlu diketahui faktor-faktor yang mempengaruhi kepuasan kerja Penyuluh Pertanian di Kecamatan Lumbis, serta hubungan antara kepuasan kerja dengan produktivitas penyuluh.

Jika diperlukan untuk menampilkan tabel dan gambar, maka tabel dan gambar tersebut disisipkan sebagaimana ilustrasi di atas. Sebaiknya pada Bab Pendahuluan tidak perlu ada sub judul - sub judul, kecuali memang sangat diperlukan. Jika diperlukan, maka pembagian sub judul adalah seperti di bawah ini.

\section{Metode Penelitian}

Penelitian ini dilaksanakan di Kecamatan Lumbis. Pengambilan sampel dalam penelitian ini dilakukan dengan berbagai pertimbangan seluruh elemen - elemen dari populasi yaitu menggunakan teknik sensus, menurut pendapat Arikunto (2005) yaitu jika elemen populasi relatif sedikit atau jika jumlah anggota subjek dalam populasi hanya $<$ 100 orang maka sebaiknya subjek sejumlah itu diambil seluruhnya, jumlah populasi penelitian ini sebanyak 30 responden sehingga sampel diambil seluruh pupolasi yaitu 30 responden.

Analisis data yang digunakan dalam penelitian ini adalah analisis regresi liner berganda dan analisis korelasi.

\subsection{Regresi Linier Berganda}

Menurut Kurniawan (2008), analisis regresi linear berganda digunakan untuk menganalisis besarnya hubungan dan pengaruh variabel independen yang jumlahnya lebih dari satu. Analisis regresi setidak-tidaknya memiliki 3 kegunaan, yaitu untuk tujuan deskripsi dari fenomena data atau kasus yang sedang diteliti, untuk tujuan kontrol, serta untuk tujuan prediksi. Persamaan regresi linier berganda sebagai berikut.

Dimana :

$$
\mathrm{Y}=\mathrm{b}_{0}+\mathrm{b}_{1} \mathrm{X}_{1}+\mathrm{b}_{2} \mathrm{X}_{2}+\mathrm{b}_{3} \mathrm{X}_{3}+\mathrm{b}_{4} \mathrm{X}_{4}+\mathrm{U}_{\mathrm{i}}
$$

$$
\begin{array}{ll}
\mathrm{Y} & =\text { Kepuasan kerja } \\
\mathrm{X}_{1} & =\text { Psikologi } \\
\mathrm{X}_{2} & =\text { Sosial } \\
\mathrm{X}_{3} & =\text { Fisik } \\
\mathrm{X}_{4} & =\text { Finansial }
\end{array}
$$

Analisis determinasi menunjukkan seberapa besar persentase variasi variabel independent yang digunakan dalam model dan mampu menjelaskan variasi variable dependent. $\mathrm{R}^{2}$ sama dengan 0 , maka tidak ada sedikitpun persentase sumbangan pengaruh yang diberikan variabel independent terhadap variabel dependent atau variasi variabel independent yang digunakan dalam model tidak menjelaskan sedikitpun variasi variabel dependent. Sebaliknya $\mathrm{R}^{2}$ sama dengan 1 , maka persentase sumbangan pengaruh yang diberikan variabel independent terhadap 
variable dependent adalah sempurna, atau variasi variable independent yang digunakan dalam model menjelaskan $100 \%$ variasi variable dependent.

Uji F digunakan untuk mengetahui apakah variable independent $\left(\mathrm{X}_{1}, \mathrm{X} 2 \ldots \mathrm{Xn}\right)$ secara simultan berpengaruh secara signifikan terhadap variabel dependent (Y).Atau untuk mengetahui apakah model regresi dapat digunakan untuk memprediksi variabel dependent atau tidak. Signifikat berarti hubungan yang terjadi dapat berlaku untuk populasi.

Uji t digunakan untuk mengetahui pengaruh masing-masing variabel, baik variabel bebas terhadap variabel terikat yang signifikan secara statistik. Langkah-langkah pengujian uji t sebagai berikut:

1. Menentukan Hipotesis

H0: Tidak ada hubungan secara signifikan antara variable independent dengan variabel dependent.

Ha: Ada hubungan secara signifikan antara variable independent dengan variable dependent.

2. Menetukan tingkat signifikan.

Pengujian menggunakan uji dua sisi dengan tingkat signifikan a $=5 \%$ (uji dilakukan 2 sisi karena untuk mengetahui ada atau tidaknya hubungan yang signifikan, jika 1 sisi digunakan untuk mengetahui hubungan lebih kecil atau lebih besar).

Tabel 1. Indikator dan parameter penelitian

\begin{tabular}{lll}
\hline & Indikator & \multicolumn{1}{c}{ Parameter } \\
\hline Kepuasan Kerja & $\bullet$ & Jenis pekerjaan \\
& $\bullet \quad$ Konpensasi/gaji \\
\hline Psikologi & $\bullet \quad$ Kesempatan promosi \\
& $\bullet \quad$ Kinat \\
& $\bullet \quad$ Betentraman dalam bekerja \\
\hline Sosial & $\bullet \quad$ Sikap terhadap kerja \\
& $\bullet \quad$ Hubungan baik terhadap sesama penyuluh \\
& $\bullet \quad$ Rekan kerja yang kompak \\
& $\bullet \quad$ Pimpinan yang adil dan bijksana \\
\hline Fisik & $\bullet \quad$ Pengarahan dan perintah yang wajar \\
& $\bullet \quad$ Kondisi lingkungan kerja \\
& $\bullet \quad$ Pengaturan waktu kerja dan istirahat \\
\hline Finansial & $\bullet \quad$ Kondisi kesehatan penyuluh dan umur \\
& $\bullet \quad$ Besar gaji \\
& $\bullet \quad$ Jaminan social \\
\hline & $\bullet \quad$ Tujangan \\
\hline
\end{tabular}

3. Menentukan t hitung.

4. Menentukan t table.

5. Kriteria Pengujian

Ho diterima jika T hitung $>\mathrm{T}$ table

Ho ditolak jika T hitung $<\mathrm{T}$ tabel Berdasarkan probabilitas:

H0 diterima jika Pvalue $>0,05$

Ho ditolak jika $\mathrm{P}$ value $<0,05$

6. Membandingkan t hitung dengan t tabel dan probabilitas.

\subsection{Korelasi}

Dari semua statistik yang didasarkan atas ranking (peringkat), koefisien korelasi Korelasi Spearman Rank merupakan statistik yang paling awal dikembangkan dan paling dikenal baik. Statistik ini kadang-kadang disebut rho. Disebut juga korelasi tata jenjang/rank order correlation/rank difference correlation dikembangkan oleh Charles Spearman.

Statistik ini digunakan untuk menghitung atau menentukan tingkat hubungan (korelasi) antara dua variabel yang keduanya memiliki tingkat data ordinal yaitu hubungan antara kepuasan kerja penyuluh dengan produktivitas 
kerja penyuluh. Apabila pada penelitian tingkat datanya adalah interval maka harus diubah ke dalam rankingranking yang merupakan sifat data ordinal. Membuat ranking dilakukan dengan mengurutkan data dari yang tertinggi sampai yang terendah, apabila ada data kembar (sama) ranking dijumlah dan dibagi dengan banyaknya data kembar (sama) tersebut. Suatu ukuran nonparametrik bagi hubungan antara dua variabel X (kepuasan kerja) dan Y (produktivitas kerja) diberikan oleh koefisien peringkat Spearman (1904) dalam Suci \& Jamil (2019) dan Irwanto (2020) yaitu:

$$
\text { Rs }=1-\frac{6 \sum D i^{2}}{N^{3}-N}
$$

Dimana :

$\mathrm{Rs}_{\mathrm{s}}=$ nilai koefisien Spearman

$\mathrm{Di}^{2}=$ selisih dari pasangan rank

$\mathrm{N}=$ banyaknya pasangan rank

6 = bilangan konstan

Untuk mengetahui signifikansi korelasi (hubungan) antara kepuasan kerja penyuluh dengan produktivitas kerja penyuluh menggunakan uji t dengan rumus sebagai berikut:

$$
\mathrm{t}=\frac{r \sqrt{n-2}}{\sqrt{1-r^{2}}}
$$

keterangan:

$\mathrm{t}=$ nilai $\mathrm{t}$ hitung yang di cari

$\mathrm{r}=$ koefisien korelasi

$\mathrm{r}^{2}=$ koefisien determinasi

$\mathrm{n}=$ jumlah sampel

Kriteria penarikan kesimpulan :

Ho : Tidak ada hubungan antara kepuasan kerja dengan Produktivtas kerja

H1 : Ada hubungan antara Peran Kepuasan kerja dengan Produktivtas kerja

Jika rhitung $<$ rtabel maka Ho diterima

Jika rhitung $>$ rtabel maka Ho ditolak

Untuk dapat menentukan tingkat hubungan (korelasi) antara dua variabel yaitu variabel kepuasan kerja dengan produktivitas kerja dapat dilihat pada tabel 2 berikut ini.

Menurut Sugiyono (2007) pedoman untuk memberikan interpretasi koefisien korelasi sebagai berikut:

Tabel 2. Interpretasi koefisien korelasi

\begin{tabular}{lcc}
\hline No & Interval & Korelasi \\
\hline 1 & $0,00-0,199$ & Sangat rendah \\
2 & $0,20-0,399$ & Rendah \\
3 & $0,40-0,599$ & Sedang \\
4 & $0,60-0,799$ & Kuat \\
5 & $0,80-1,000$ & Sangat Kuat \\
\hline
\end{tabular}

\section{Hasil dan Pembahasan}

\subsection{Faktor-Faktor yang Memengaruhi Kepuasan Kerja Penyuluh Pertanian}

Model yang dihasilkan dari persamaan regresi adalah:

$$
\mathrm{Y}=0,117+0,360 \mathrm{X}_{1}+0,368 \mathrm{X}_{2}+0,046 \mathrm{X}_{3}+0,208 \mathrm{X}_{4}
$$

Konstanta sebesar 0,117 menunjukan apabila psikologi $\left(\mathrm{X}_{1}\right)$, sosial $\left(\mathrm{X}_{2}\right)$, fisik $\left(\mathrm{X}_{3}\right)$, finansial $\left(\mathrm{X}_{4}\right)$ diabaikan atau nol, maka kepuasan kerja penyuluh pertanian Lapangan Kecamatan Lumbis (Y)sebesar 0,117.

Koefisien variabel psikologi $\left(\mathrm{X}_{1}\right)$ 0,360. Berarti jika variabel psikologi dinaikkan 1 satuan, maka kepuasan kerja penyuluh naik sebesar 0,360 satuan. Koefisien variabel psikologi bertanda positif. Berarti semakin baik aspek psikologi maka kepuasan kerja penyuluh meningkat. 
Koefisien variabel sosial $\left(\mathrm{X}_{2}\right)$ 0,368. Berarti jika variabel sosial dinaikkan 1 satuan, maka kepuasan kerja penyuluh naik sebesar 0,368 satuan. Koefisien variabel sosial bertanda positif. Berarti semakin baik aspek sosial maka kepuasan kerja penyuluh meningkat.

Koefisien variabel fisik $\left(\mathrm{X}_{3}\right)$ 0,046. Berarti jika variabel fisik dinaikkan 1 satuan, maka kepuasan kerja penyuluh naik sebesar 0,046 satuan. Koefisien variabel fisik bertanda positif. Berarti semakin baik aspek fisik maka kepuasan kerja penyuluh meningkat.

Koefisien variabel finansial $\left(\mathrm{X}_{4}\right)$ 0,208. Berarti jika variabel finansial dinaikkan 1 satuan, maka kepuasan kerja penyuluh naik sebesar 0,208 satuan. Koefisien variabel fisik bertanda positif. Berarti semakin baik aspek finansial maka kepuasan kerja penyuluh meningkat.

\subsubsection{Koefisien Determinasi $\mathbf{R}^{2}$ (R Square)}

Untuk mengetahui besarnya pengaruh variabel psikologi, sosial, fisik, finansial terhadap kepuasan kerja penyuluh pertanian lapangan Kecamatan Lumbis $(\mathrm{Y})$ digunakan koefesien R Squere $\left(\mathrm{R}^{2}\right)$. Berdasarkan analisis nilai $\mathrm{R}^{2}$ sebesar 0,942 . Hal ini berarti bahwa kepuasan kerja penyuluh dipengaruhi variabel psikologi, sosial, fisik, finansial sebesar 94,2\%. Adapun sisanya sebesar 5,8\% dipengaruhi oleh variabel lain diluar penelitian ini.

\subsubsection{Uji F}

Uji F digunakan untuk mengetahui apakah variabel independent (psikologi, social, fisik dan finansial) secara bersama sama berpengaruh secara signifikan terhadap variabel dependent (kepuasan kerja penyuluh).

Nilai signifikan F statistik sebesar 0,000, F sig $(0,000)<0,05$. Sehingga H0 ditolak, H1 diterima. Hal ini berarti secara signifikan terdapat pengaruh variabel psikologi $\left(\mathrm{X}_{1}\right)$, sosial $\left(\mathrm{X}_{2}\right)$, fisik $\left(\mathrm{X}_{3}\right)$, finansial $\left(\mathrm{X}_{4}\right)$ terhadap kepuasan kerja penyuluh pertanian lapangan Kecamatan Lumbis (Y).

\subsubsection{Uji Parsial (t-test)}

Uji hipotesis t digunakan untuk mengetahui apakah variabel bebas memiliki hubungan signifikan atau tidak dengan variabel terikat secara individual untuk setiap variabel.

Tabel 3. Hasil uji parsial

\begin{tabular}{cccc}
\hline No & Varibel & T & Sig \\
\hline 1 & Constant & 1,039 & 0,000 \\
2 & Psikologi X1 & 3,571 & 0,001 \\
3 & Sosial X2 & 3,723 & 0,001 \\
4 & Fisik X3 & 0,935 & 0,359 \\
5 & Finansial X4 & 2,623 & 0,015 \\
\hline
\end{tabular}

Variabel psikologi $\left(\mathrm{X}_{1}\right)$ nilai hasil signifikan sebesar 0,001. Sehingga H0 ditolak H1 diterima $(0,001<0,05)$, berarti variabel psikologi berpengaruh terhadap kepuasan kerja penyuluh. Seluruh penyuluh menyatakan bahwa pekerjaan sebagai penyuluh merupakan pekerjaan yang mereka inginkan, sesuai dengan bakat yang mereka miliki serta menimbulkan rasa nyaman dalam bekerja, dengan demikian mereka merasa semangat yang berpengaruh terhadap kepuasan kerja. Hal ini sejalan dengan pendapat Hubeis (2007), bahwa factor psikologis berpengaruh terhadap kepuasan kerja.

Variabel sosial $\left(\mathrm{X}_{2}\right)$ diperoleh nilai hasil signifikan sebesar 0,001. Sehingga H0 ditolak H1 diterima $(0,001<$ $0,05)$, berarti variabel sosial berpengaruh terhadap kepuasan kerja penyuluh. Adanya hubungan yang baik terhadap sesama penyuluh, rekan kerja yang kompak, pimpinan yang adil dan bijaksana, serta kordinasi yang baik mempengaruhi kepuasan kerja penyuluh dalam melaksanakan tugasnya, seperti yang dinyatakan Hapsari dkk (2014), bahwa keharmonisan antar pekerja berpengaruh terhadap kepuasan kerja.

Variabel fisik $\left(\mathrm{X}_{3}\right)$ diperoleh nilai hasil signifikan sebesar 0,359. Sehingga H0 terima H1 tolak $(0,359>0,05)$ , berarti variabel fisik tidak berpengaruh terhadap kepuasan kerja penyuluh. Hal tersebut karena jangkauan wilayah kerja tidak jauh dan didukung transfortasi sehingga tidak memerlukan kondisi fisik yang kuat selain itu pengaturan waktu kerja dan istirahat, kondisi kesehatan penyuluh dan umur tidak menjadi kendala bagi penyuluh. Pengaturan waktu kerja dan istirahat merupakan indikator yang dianggap penting, dengan tertatanya waktu kerja dan istirahat maka target kerja dapat terpenuhi (Hapsari dkk, 2014) .

Variabel finansial $\left(\mathrm{X}_{4}\right)$ diperoleh nilai hasil signifikan sebesar 0,015. Sehingga H0 ditolak H1 diterima (0,015 $<0,05)$, berarti variabel finansial berpengaruh terhadap kepuasan kerja penyuluh. Besarnya gaji, jaminan sosial, tunjangan, fasilitas yang diterima penyuluh mempengaruhi kepuasan kerja penyuluh. Hal ini sependapat dengan hasil penelitian Nasution dan Musnadi (2018), bahwa terdapat pengaruh antara faktor finansial terhadap kepuasan kerja

\subsection{Hubungan Kepuasan Kerja dengan Produktivitas Penyuluh Pertanian}

Dari hasil analisis rank spearman hubungan kepuasan kerja dengan produktivitas penyuluh pertanian lapangan Kecamatan Lumbis dapat dilihat Tabel 4 sebagai berikut: 
Tabel 4. Hasil korelasi menggunakan analisis Rank Spearman

\begin{tabular}{lllll}
\hline & & Kepuasan Kerja & Produktivitas Kerja \\
\hline Spearman's rho & Kepuasan Kerja & Correlation Coefficient & 1,000 &, $643^{* * *}$ \\
& & Sig. (2-tailed) & $\cdot$ &, 007 \\
& N & 30 & 30 \\
& Produktivitas Kerja & Correlation Coefficient &, $643^{* * *}$ & 1,000 \\
& Sig. (2-tailed) &, 007 &. \\
& N & 30 & 30 \\
\hline
\end{tabular}

Pada Tabel 3 dapat dilihat hasil perhitungan korelasi Rank spearman diperoleh angka koefisien korelasi sebesar 0.643 artinya tingkat kekuatan hubungan (korelasi) antar variabel kepuasan kerja dengan produktivitas kerja penyuluh adalah sebesar 0.643 atau hubungan kuat. Angka koefisien korelasi pada hasil diatas juga bernilai positif yaitu 0.643 yang artinya hubungan atara kedua variabel (kepuasan kerja dan produktivitas kerja) bersifat searah atau dapat diartikan bahwa dengan meningkatnya kepuasan kerja penyuluh maka produktivitas kerja penyuluh juga akan meningkat. Hal ini sejalan dengan pendapat Almigo (2014) bahwa ada hubungan positif yang signifikan antara kepuasan kerja dengan produktivitas kerja. Hal ini menunjukkan bahwa semakin tinggi kepuasan kerja yang diterima karyawan, semakin tinggi pula produktivitas kerjanya, namun berbeda dengan hasil penelitian Fuadi (2014) bahwa kepuasan kerja mempunyai pengaruh negatif tidak signifikan terhadap produktivitas kerja guru SMA Muhammadiyah I Klaten

Kepuasan kerja penyuluh di Kecamatan Lumbis yang diukur dari aspek psikologis, social, fisik, dan finansial berkorelasi dengan produktivitas kerja penyuluh, karena ketika penyuluh merasa bangga sebagai agen of change, memiliki relasi sosial yang baik dengan kelompok tani binaan, termasuk dengan aparat desa dan tokoh masyarakat setempat, sehingga ada perasaan nyaman dan aman secara hubungan social.

Kondisi fisik penyuluh yang mendukung juga memberikan semangat dalam melaksanakan dan menyelesaikan tugas-tugas sebagai penyuluh. Menurut Muizzudin (2013), jika pekerja merasa kelelahan secara fisik akan mempengaruhi produktivitas kerjanya. Selain itu kemampuan fisik dalam hal ini keterampilan kerja juga berhubungan dengan produktivitas kerja (Syahdan, 2017).

Aspek finansial adalah salah satu aspek yang berpengaruh terhadap produktivitas kerja, karena penyuluh akan merasa puas karena dapat memenuhi kebutuhan hidupnya dan memiliki rasa tanggungjawab dalam melaksanakan perannya sebagai penyuluh. Seperti yang dikemukakan oleh Muayyad dan Gawi (2017), bahwa salah satu faktor penentu ketidakpuasan pegawai dapat diduga karena gaji, insentif dan motivasi yang diterima kurang sesuai dengan tanggung jawab pekerjaan dan tingkat resiko yang dimiliki dari pekerjaan tersebut. Sementara Alimuddina (2012) menyatakan bahwa variabel kompensasi finansial dan kompensasi non-finansial secara simultan mempunyai pengaruh yang positif dan signifikan terhadap produktivitas karyawan, dimana variabel yang dominan adalah kompensasi finansial.

\section{Kesimpulan dan Saran}

\subsection{Kesimpulan}

Berdasarkan hasil penelitian menunjukkan bahwa Variabel psikologi $\left(\mathrm{X}_{1}\right)$, sosial $\left(\mathrm{X}_{2}\right)$, dan finansial $\left(\mathrm{X}_{4}\right)$, mempengaruhi kepuasan kerja penyuluh di Kecamatan Lumbis dengan nilai signifikansi 0,000 pada taraf 5\% atau 0,05. Koefisien korelasi sebesar 0.643 artinya tingkat kekuatan hubungan (korelasi) antar variabel kepuasan kerja penyuluh dengan produktivitas penyuluh adalah sebesar 0.643 atau hubungan kuat. Dengan kata lain, tingginya kepuasan rendah akan memberikan konsekuensi terhadap peningkatan tingkat produktivitas penyuluh pertanian dalam menjalankan tugas dan fungsinya.

\subsection{Saran}

Untuk meningkatkan peran penyuluh perlu dukungan sarana, prasarana serta partisipasi baik dari pemerintah maupun masyarakat.

\section{Daftar Referensi}

Alimuddin, W. (2012). Pengaruh Kompensasi Terhadap Produktivitas Karyawan Pada PT. Bakrie Telecom Area Makassar. Skripsi. Universitas Hasanudin. Makasar

Almigo, N. (2014). Hubungan antara kepuasan kerja dengan produktivitas kerja karyawan. Jurnal Psyche, 1(1), $50-60$

Fuadi, A. A. (2014). Pengaruh Kepemimpinan, Budaya Organisasi dan Kepuasan Kerja terhadap Produktivitas Kerja Guru dengan Komitmen Organisasi Sebagai Moderating. Informatika, 1(2). 
Hapsari, R., Astuti, R., \& Anggarini, S. (2014). Pengaruh Faktor-Faktor Kepuasan Kerja Terhadap Produktivitas Kerja Karyawan (Studi Kasus di Bakso Bakar Pahlawan Trip, Malang). Universitas Brawijaya Malang

Handoko, H. (2001). Manajemen Personalia dan Sumber Daya Manusia. Yogyakarta: BPFE Jogja.

Hubeis, A. V. S. (2007). Motivasi, kepuasan kerja dan produktivitas penyuluh pertanian lapangan: Kasus Kabupaten Sukabumi. Jurnal Penyuluhan, 3(2).

Irwanto. (2019). Analisis Hubungan Karakteristik dengan Kinerja Penyuluh Pertanian di Kabupaten Batang Hari Provinsi Jambi. Jurnal AgroSainTa: Widyaiswara Mandiri Membangun Bangsa, 3(1): 47-54.

Kurniawan, D. (2008). Regresi Linier. R-Foundation for Statistical Computing. Vienna, Austria, 17.

Muayyad, D. M., \& Gawi, A. I. O. (2017). Pengaruh Kepuasan Kerja Terhadap Produktivitas Kerja Pegawai Bank Syariah X Kantor Wilayah II. Jurnal Manajemen dan Pemasaran Jasa, 9(1), 75-98.

Muizzudin, A. (2013). Hubungan Antara Kelelahan Kerja dengan Produktivitas Kerja pada Tenaga Kerja Bagian Tenun di PT. Alkatex Tegal (Doctoral dissertation, Universitas Negeri Semarang).

Nasution, E. H., \& Musnadi, S. (2018). Faktor-Faktor yang Mempengaruhi Kepuasan Kerja dan Dampaknya terhadap Kinerja Pegawai Kanwil Direktorat Jenderal Kekayaan Negara Aceh. Jurnal Magister Manajemen, 2(1), 123-134.

Suci, Y. T. \& Jamil, A. S. (2019). Hubungan Tingkat Kepuasan Pelayanan dengan Keberhasilan Peserta Pelatihan Teknis bagi Penyuluh Pertanian. Jurnal Hexagro, 3(2): 47-55.

Sugiyono. (2011). Statistik Untuk Penelitian. CV. Alfabeta. Bandung

Suryana, N. K., \& Ningsih, D. S. (2018). Peran Penyuluh Pertanian Dalam Pemberdayaan Kelompok Tani (Studi Kasus Kelompok Tani Subur Di Desa Karang Agung Kabupaten Bulungan). Jurnal Borneo Humaniora, 1(1), 01-06

Suryana, N. K. (2021). Analisis Motivasi Kerja Penyuluh Pertanian di Kota Tarakan. in prosiding seminar nasional hukum dan pembangunan yang berkelanjutan (pp. 52-60).

Syahdan, F. (2017). Hubungan antara keterampilan kerja dengan produktivitas kerja. Psikoborneo, 5(1), 1-10. 